\title{
WOMEN'S EMPLOYMENT IN THE AGRICULTURAL SECTOR IN THE DEVELOPMENT PROCESS OF TURKEY
}

\author{
DOI: 10.17261/Pressacademia.2020.1204 \\ JEFA- V.7-ISS.2-2020(1)-p.75-85
}

\section{Zeynep Colak}

Canakkale Onsekiz Mart Universty, Biga Faculty of Economics and Administrative Sciences, Department of Business, Canakkale, Turkey. zolak.84@gmail.com, ORCID: 0000-0003-0058-6809

\begin{tabular}{l}
\hline Date Received: March 2, $2020 \quad$ Date Accepted: May 30, 2020 \\
\hline To cite this document \\
Colak, Z., (2020). Women's employment in the agricultural sector in the development process of Turkey. Journal of Economics, Finance and \\
Accounting (JEFA), V.7(2), p.75-85. \\
Permanent link to this document: $\underline{\text { http://doi.org/10.17261/Pressacademia.2020.1204 }}$ \\
Copyright: Published by PressAcademia and limited licensed re-use rights only.
\end{tabular}

\section{ABSTRACT}

Purpose- The aim of this study is to demonstrate the relationship between Turkey's development process, with the transformation of the agricultural sector in female employment in the agricultural sector. The state of the agricultural sector in the development process of Turkey in this context is realized in which the female employment rate in the agriculture sector and employment of women in the agricultural sector during this period has been studied how to be an impact on the agricultural production value.

Methodology- Data for the years 2000-2018 for Turkey, which is a relational scanning model of quantitative research methods LS-Least Squares (NLS and ARMA) has been the method of analysis.

Findings- According to the findings obtained as a result of the analysis, female employment in the agricultural sector had a positive effect on both nominal and real production values of agricultural products.

Conclusion- Based on the positive impact of female employment in the agricultural sector on both nominal and real production values of agricultural products such as vegetables, fruit and spice crops, other than cereals, and other vegetable crops, women's employment in agriculture is a very important factor in the development process of the agricultural sector.

Keywords: Development, agriculture economy, women employment, gender.

JEL Codes: J16, Q19, 013

\section{INTRODUCTION}

The development has been a more frequent concept, especially after the Second World War. As one of the primary elements of the founding ideological structure of most states, development plays an important role in shaping political practices and institutions. This is also a factor that makes the social structure valid for the disciplines that establish gender-based.

According to Boserup (1970), the different issues on the role of women in the economy drew attention to a systematic way by the women that vary significantly between countries and regions. Emphasizing that women have a central role in African agriculture, as opposed to the limited roles they have in Asia and Latin America, Boserup's analysis indicated that there is a mutual relationship between women's work and factors such as population density and land ownership. It also showed that there is a relationship between these factors and the secondary of women in different ways. Comparative analysis of Boserup reflected the patterns of women's participation in the non-agricultural activities of the sexist division of labor in agricultural systems. For example, he noted the impact of farming systems on migration patterns and the inclusion of women and men in the urban labor market (Yavuz et al., 2010, p. 49-101). However, according to the ongoing practices, in the sectors where all production for exchange is carried out depending on the wage system, women spend unrequited labor in non-exchange production.

The family production style - the exploitation of women's unpaid labor - does not apply to exchange-oriented productions. What is at stake here is the exchange by the husband. For example, the equivalent of women's agricultural labor is not paid to her if she carries out this work within the family; that is, it cannot exchange this product that it produces in the family in the market. Therefore, it is not in the saving of labor. The only person who holds the savings of the labor force of women is 
her husband, who can exchange her product in the market. Likewise, if it is carried out in the family, the woman does not have the products of domestic production and she can exchange them only outside the family. Thus, women's production always has exchange value, provided that it falls outside the family framework.

However, less developed countries, particularly to solve the problems of the people in the rural areas, various rural development programs implemented. The fact that agricultural employment is important for the country's economies requires the projects to have an agricultural aspect. With these projects, it is aimed to ensure gender equality and women's employment will become more qualified (Tolunay et al., 2006, p. 116-127).

In Africa, women are often in the agricultural sector and the presence of women and children in the village leads to an outcome that migration composes of male migration. While women in Africa generally have a pattern of male-intensive migration from rural to urban as a result of the presence of women in agriculture, the employment of more men than women in the agricultural sector causes a high level of female migration and therefore employment areas are opened in urban centers for young women (Yavuz et al., 2010, p. 49-101).

In the context of the current growth model, a detailed discussion is taking place regarding the dynamics related to the increase in women's employment in agriculture, structural adjustment programs, and crises, poverty and microfinance agriculture. The discussion is also evaluated in terms of the transformation of the rural agriculture sector in different parts of the world. It is seen that the idea of development is redefined, especially in regions characterized by different forms of labor. Also, the effects of differentiation in gender relations in this context are quite high (Balaban, 2012, p. 177-182).

The importance of agriculture, which plays an important role in the development of countries and societies, is gradually increasing with the effect of the globalizing economic system, increasing competition environments, and rapidly changing market conditions. Surrounded by the sea on three sides due to its geopolitical position in which Turkey's rivers and ecological diversity due to plant owned, has special importance for the animal and aquaculture. (Dogan et al., 2005, p. 367). Agricultural support policies implemented in Turkey until the 2000s, supporting procurement, input subsidies, and credit products and has made other subsidies for agriculture. While the number of herbal products included in the price support was around 20 in the 1970s, it decreased to 10 with the effect of the market economic policies in the 1980s, but it increased to over 20 again in the 90s. Input subsidies, fertilizer, seed, feed, pesticides, irrigation, breeding, animal and artificial insemination have been implemented, though not continuously. The fact that all these support policies did not make the agricultural sector successful at the desired level and brought heavy burdens to the budget enabled the transition to new support policies and especially Direct Income Support with the support of international organizations (Yavuz, 2005, p. 43-67).

It meets a significant part of the nutritional requirements required for people to continue their vital activities and generations from ages to the present day. For this reason, one of the biggest contributions of agricultural activities to the economy is the contribution of agricultural products. According to Doğan (2005), it is not possible for a man to turn to other economic activities and develop them without meeting their primary nutritional needs (Dogan, 2005, p. 367).

Agricultural production in Turkey, within the framework of the employment of women, is very important in terms of 2: On the one hand agriculture in recent years the value of women's major employment areas there has been, on the other hand, agricultural production has been a manufacturing process using intense of female labor (Öztürk and Akduran, 2012, p. 87101). In Turkish society, peasant women participate in production to a large extent and contribute to economic life. On the one hand, agriculture has been the main employment area of women until the last years, on the other hand, agricultural production has been a production process in which women's labor is used extensively. In fact, in addition to the participation of rural women as a family, workforce, waged agricultural worker, and business manager, they also contribute economically to the family through non-agricultural activities (carpet-rug weaving, etc.) (Kantar, 1996). The female labor force participation rate, that is, the proportion of those who are economically active in the female population is influenced by a large number of socio-economic factors and is universally lower than the male labor force participation rate. The state of the period as Turkey has developed or underdeveloped similar points with all countries (Makal, 2001, p. 117-155). Women in underdeveloped regions have a higher share for unpaid family workers and self-employed. Especially it is impossible to talk about women's economic freedom. The transition from this type of employment to wage employment is a prerequisite to affect women's economic freedom and free decision making (Cakir, 2008, p. 25-47). In fact, unemployment rates are estimated to be much higher among women. In order to grasp the dimensions of this, it is also necessary to take into account those who are ready to work but who are not looking for a job and those who are still looking for a job while still working in a job.

As the agricultural production declined, the masses, which had no employment opportunities in rural areas and could not overcome the increasing poverty, quickly migrated to the cities. Rural to urban migration has created several negative consequences from employment to housing. However, as long as the migration process affects female employment, it has greater disadvantages for women than men. (Öztürk et al., 2012, p. 87-101). Migration from rural areas to cities, internal migration; in agriculture, especially women who work as unpaid family workers are out of business life in cities. The women 
in this category, who lack the education and qualifications required to be in the business life in the city, generally lead their lives as housewives, and their participation in the labor force remains at a much lower level compared to the rural areas. This will inevitably occur in the form of a big decrease in the labor force participation rate for women who are fully in the labor force. There is a negative relationship between urbanization and women's participation in the labor force and the proportion of women in the labor force, but it is observed that the ratio shows a small increase in terms of large cities (Makal,2001, p. 117-155).

In this study, the current situation of the agricultural sector in Turkey's development process, the process of women's employment in the agricultural sector with the effects of female employment in the agricultural sector, the possible effects on agriculture production values were examined. In the introduction part of the article, the terms of development and rural development are defined and the historical process of women employment in agriculture is given in the rural development process. Then a literature review of women's employment in agriculture has been made. Studies, which conducted both Turkey and other countries, are included about which products are higher on the employment of woman. In the third and fourth sections of the agricultural arrangements in the development of women in Turkey findings have been reviewed by analyzing in Turkey's development and transformation of the agricultural sector of women's employment. In the last section, the results of the analysis of the latest data are discussed.

\section{LITERATURE REVIEW}

Kazgan (1983) stated that unless the weight of agriculture increases in the economy, it would not be possible to achieve development in non-agricultural sectors. For this reason, the countries at the beginning of their development have to increase their agricultural productivity in order to ensure their economic development (Kazgan, 1983:439).

In their study, Tolunay and Akyol (2006) state that the most important factor in the increase in agricultural employment in the country's economies is to establish projects aiming at ensuring gender equality and making women employment more qualified (Tolunay et al., 2006: 122).

According to Boserup (1970), when the sustainability of agriculture and industrialization are evaluated in the context of gender, the importance of gender discrimination in employment in the field of agriculture and industry and the role played by gender relations play an important role in economic development. According to this idea, In his study, Tire (2017) establishes an important link between the wages of women and the data they bring with them in their economic development, and the economy of market production with the contribution of women to agricultural production (Tire, 2017: 97)

In the study of Şahin (2002), it has revealed that one of the contributions of the agriculture sector to the economy in developing countries is the foreign currency contribution provided through exports. The most important product to be exported in these countries is agricultural products. Thus, most of the foreign currency entering the country is provided by agriculture. Foreign exchange revenues from the export of agricultural products are used in the purchase of investment goods and inputs that the country needs to improve its industrial production (Şahin, 2002:272).

According to Raney (2011), women contribute significantly to the development of the agricultural and rural economy of developing countries.

Şahin (2002)'s study revealed that one of the contributions made by the agricultural sector to the economy in developing countries is the foreign exchange contribution made through exports. Thus, most of the foreign currency entering the country is provided from agriculture. Foreign exchange revenues from the export of agricultural products are used for the purchase of investment goods and inputs that the country needs to improve its industrial production (Şahin, 2002, s.272).

According to Hablemitoğlu (1998), female labor in the production process in agriculture provides the product for the market, and maintains the agricultural system and improves the family's economic well-being (Hablemitoğlu, 1998:32-35).

lyengar (2016)'s econometric study for India's Chhattisgarh State showed that women play an important role in the agricultural sector for the economy of Chhattisgarh and that women are engaged in agriculture especially with rice, pulses and a lot of oilseed production (lyengar et al., 2016: 2).

Rahman (2000) in his analysis for Bangladesh shows that the increase in the production of non-grain products such as spices, oilseeds, vegetables has a high potential to increase the lucrative employment of women in agriculture (Rahman, 2000, s. 497-507). 


\section{DATA AND METHODOLOGY}

\subsection{Research Pattern}

Turkey's development process and in the transformation of the agricultural sector in this research in a relational scanning model that examines the role of gender within the scope of women's employment in this transformation, quantitative research methods were used. The screening model is based on showing the current situation as it is, determining the existing one as it is. (Karasar, 2018). In the relational scanning model, which is a type of scanning model; an attempt is made to measure whether and/and the degree of co-variation between two or more variables (Karasar, 1999).

\subsection{Data Set}

In this study, the period between the years 2000-2018 with the transformation of the agricultural sector in Turkey's development process aimed to reveal the relationship between women's employment in the agricultural sector. Within the scope of the research, answers to the following questions were sought. These;

1. What is the status of the agricultural sector in the development process of Turkey between the years of 2000 to 2018 ?

2. In the development process of Turkey between 2000 and 2018, at what rates did female employment in the agricultural sector occur?

3. How did women's employment in the agricultural sector have an impact on agricultural production values during this period?

The equations created in this context are listed below.

$$
\begin{aligned}
& l n \_n \_ \text {agriculture } 2 t=\beta 0+\beta 1 \text { ln_women_emp_rate } 1 t+e t \\
& l n \_n \_g r a i n 2 t=\beta 0+\beta 1 n_{-} \text {women_emp_rate } 1 t+e t \\
& \text { ln_n_vegetable } 2 t=\beta 0+\beta 1 \text { ln_women_emp_rate } 1 t+e t \\
& l n \_n \_f r u i t 2 t=\beta 0+\beta 1 \text { ln_women_emp_rate } 1 t+e t \\
& \text { ln_r_agriculture } 2 t=\beta 0+\beta 1 \text { ln_women_emp_rate } 1 t+e t \\
& l n \_r \_g r a i n t=\beta 0+\beta 1 \text { ln_women_emp_rate } 1 t+e t \\
& \text { In_r_vegetable } 2 t=\beta 0+\beta 1 \text { In_women_emp_rate1t +et } \\
& \text { In_r_fruit } 2 t=\beta 0+\beta 1 \text { In_women_emp_rate } 1 t+e t
\end{aligned}
$$

the phrase "agriculture" refers to the production values of all agricultural products; "grain" expression, the production values of cereals and other plant products; "vegetable" expression, the production values of vegetable products; "fruit" means the production values of fruits, beverages and spice plants; the phrase "women_emp_rate" refers to the ratio of women employment in agriculture (women employment/total employment);

The expression " 1 " is taken from the first-order difference; The phrase " 2 " is quadratic;

the expression "In" applied to the logarithmic transformation; the " $n$ " expression is "nominal" i.e. the value of the production value in "billion TL"; the expression" $r$ " means "real" i.e. the value of production values in "billion dollars" (billion TL/dollar exchange rate).

All data in the scope of the research are available from the official website of the Turkish Statistical Institute (www.tuik.gov.tr) has been obtained.

The descriptive statistics for the research variables are below in Table 1. 
Tablo 1: Descriptive Statistics for the Variables

\begin{tabular}{|l|c|c|c|c|}
\hline Variable & $\begin{array}{c}\text { Minimum } \\
\text { Observed } \\
\text { Value }\end{array}$ & $\begin{array}{c}\text { Maximum } \\
\text { Observed } \\
\text { Value }\end{array}$ & Mean & $\begin{array}{c}\text { Standard } \\
\text { Deviation }\end{array}$ \\
\hline n_agriculture & 14,92 & 159,14 & 75,36 & 39,42 \\
\hline n_grain & 6,60 & 62,22 & 30,26 & 15,78 \\
\hline n_vegetable & 14,92 & 159,14 & 75,36 & 39,42 \\
\hline n_fruit & 4,64 & 55,53 & 24,80 & 13,62 \\
\hline r_agriculture & 16,27 & 53,32 & 38,90 & 10,88 \\
\hline r_grain & 7,24 & 21,37 & 15,59 & 3,81 \\
\hline r_vegetable & 4,35 & 17,71 & 10,59 & 3,64 \\
\hline r_fruit & 4,69 & 18,42 & 12,72 & 3,82 \\
\hline women_emp_rate & 44,42 & 49,26 & 46,55 & 1,26 \\
\hline
\end{tabular}

Looking at the table, it is seen that;

The mean for the nominal production values of all agricultural products is 75,36 billion TL; the minimum observed value is 14,92 billion TL (2000), the maximum observed value is 159,14 billion TL (2018),

The mean for the nominal production values of cereals and other crops is 30,26 billion TL; the minimum observed value is 6,60 billion TL (2000), the maximum observed value is 62,22 billion TL (2018),

The mean for the nominal production values of vegetable products is 75,36 billion TL; the minimum observed value is 14,92 billion TL (2000), the maximum observed value is 159,14 billion TL (2018),

The mean for the nominal production values of fruits, drinks and spice plants is 24,80 billion TL; the minimum observed value is 4,64 billion TL (2000), the maximum observed value is 55,53 billion TL (2018),

The mean for the real production values of all agricultural products is 38,90 billion dollars; the minimum observed value is 16,27 billion dollars (2001), the maximum observed value is 53,32 billion dollars (2010),

The mean for the real production values of cereals and other crops is 15,59 billion dollars; the minimum observed value is 7,24 billion dollars (2001), the maximum observed value is 21,37 billion dollars (2011),

The mean for the real production values of vegetable products is 10,59 billion dollars; the minimum observed value is 4,35 billion dollars (2001), the maximum observed value is 17,71 billion dollars (2010),

The mean for the real production values of fruits, drinks and spice plants is 12,72 billion dollars; the minimum observed value is 4,69 billion dollars (2001), the maximum observed value is 18,42 billion dollars (2008),

The mean for the ratio of women employment in agriculture is $\% 46,55$; the minimum observed value is $\% 44,42(2018)$, the maximum observed value is \%49,26 (2002),

The graphics of the variables within the scope of the research are given below: 
Figure 1: 2000-2018 Chart of Nominal Production Values of Agricultural Products

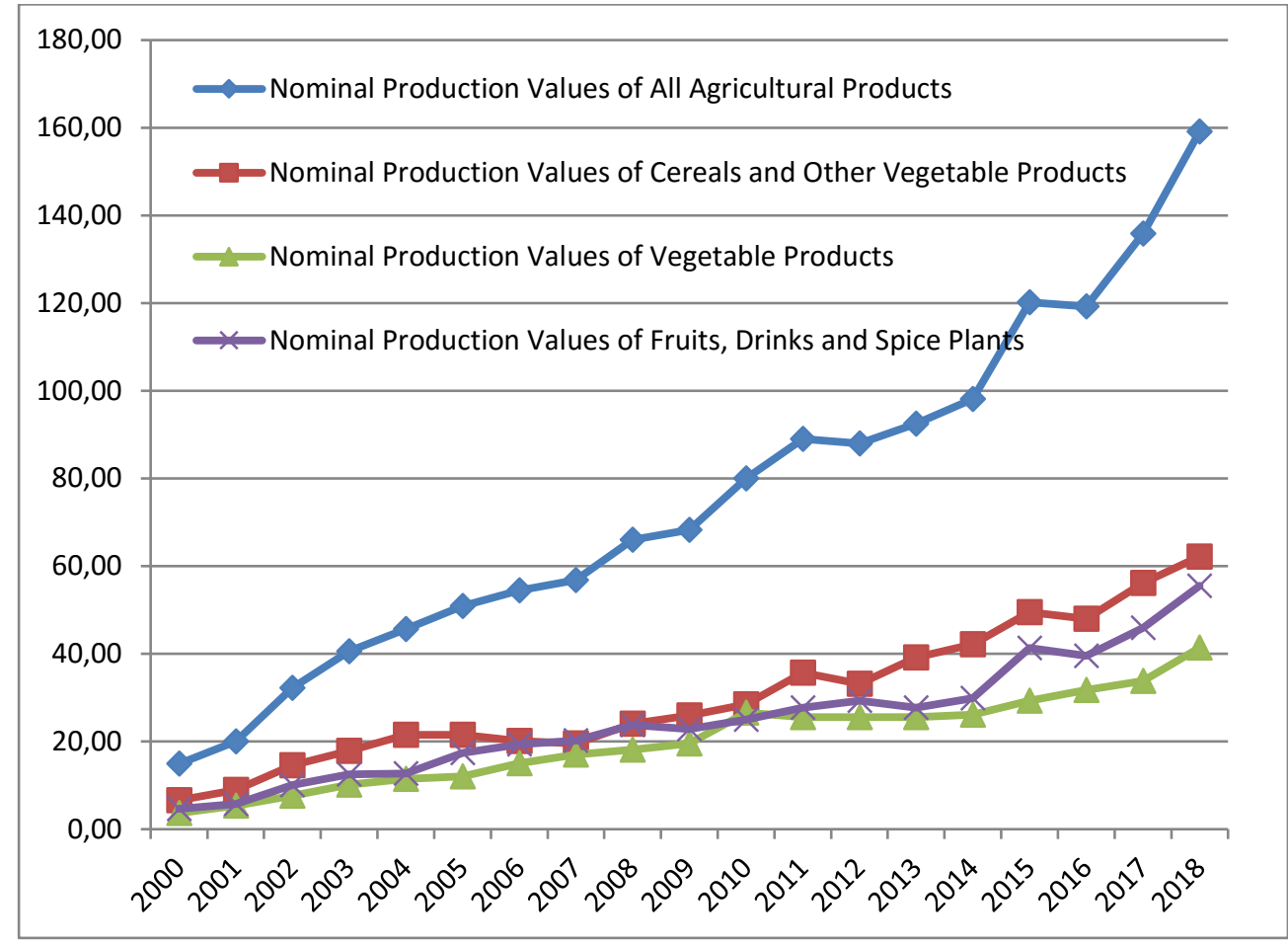

The nominal production values of agricultural products between 2000 and 2018 are shown in Figure 1. In this period, there is a steady increase in the nominal production values of both agricultural products in all three categories (Cereals and other crop products; vegetable products; fruits, beverages and spice plants) and all agricultural products in these three categories. The nominal production value of all agricultural products, which was 14.92 billion TL in 2000, reached 159.14 billion TL in 2018.

Figure 2: 2000-2018 Chart of Real Production Values of Agricultural Products

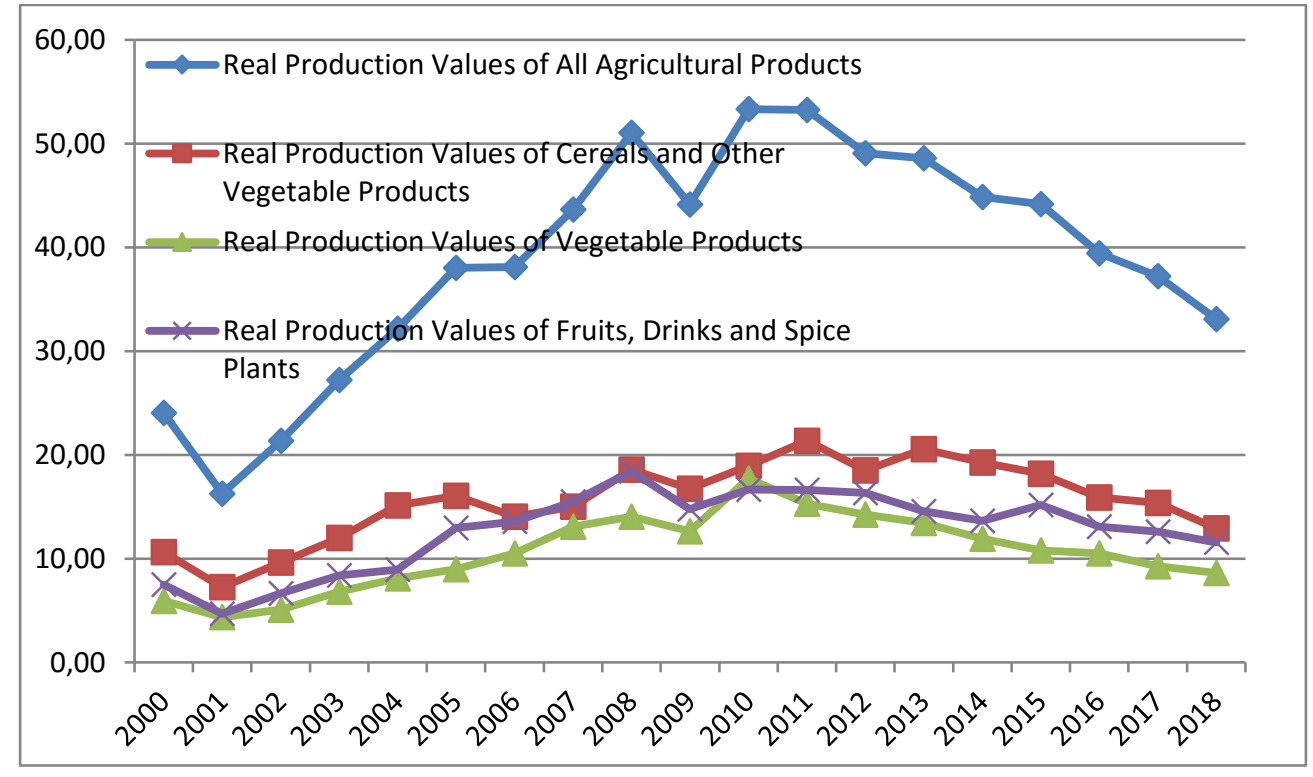


Real production values of agricultural products between 2000-2018 are shown in Figure 2 . In this period, it has been a very serious decrease at levels of $30 \%$ in the real production values of both agriculture products in all three different categories(Grains and other crop products; vegetable products; fruits, beverages and spice plants) and agriculture products in these three categories in the 2000-2001 period, it has been a steady increase since this period. The steady increase period starting after 2001 continued until 2008 for fruits, beverages and spice crops, until 2010 for vegetable products and all agricultural products and 2011 for cereals and other crop products. As of these dates, there is a steady decline in agricultural products in all categories with very few exceptions. Although the real production value of all agricultural products, which was 24.06 billion dollars in 2000, reached to 53.32 billion dollars of the highest value in 2010, this value decreased to 33.07 billion dollars in 2018.

Figure 3: 2000-2018 Dollars / TL Rate

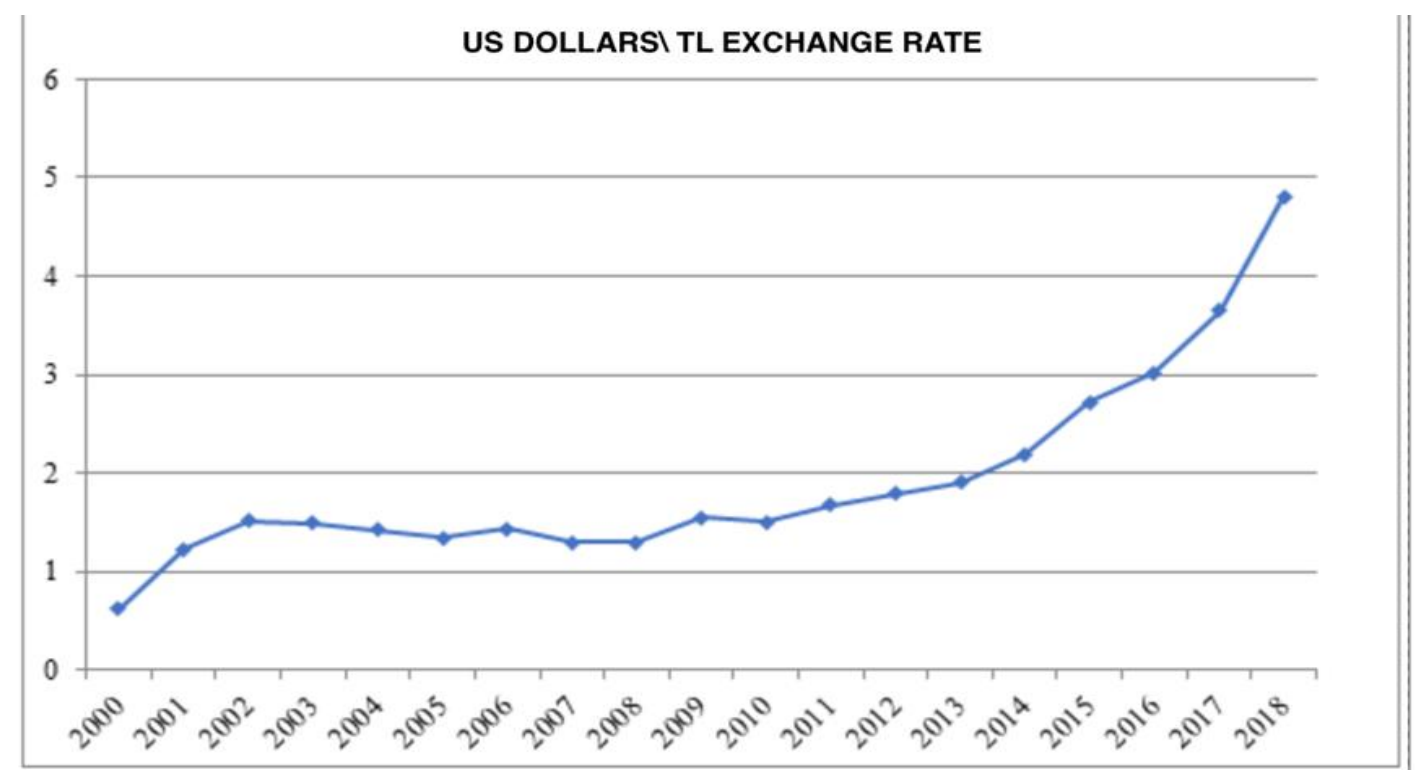

The dollar/TL exchange rate chart for the years 2000-2018 is shown in Figure 3. The dollar/TL rate, which showed a linear increase between 2000-2002, followed a floating but horizontal course between 2002-2010. The dollar/TL rate, which has risen since 2010, has increased slightly between 2010 and 2014 and sharply between 2014-2018.

Figure 4: 2000-2018 Chart of Female Employment Rate in Agricultural Sector

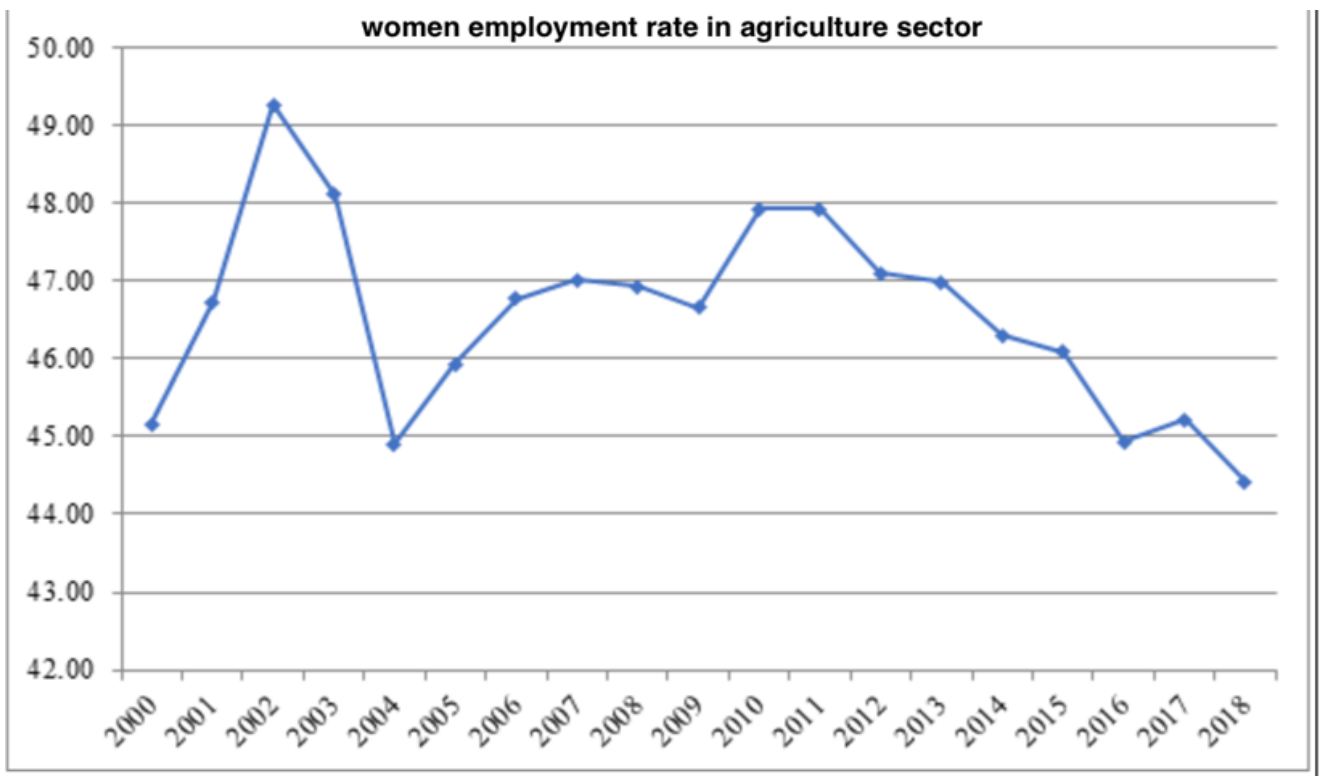


Female employment rate in the agricultural sector between 2000 and 2018 is shown in Figure.4. The employment rate of women in the agriculture sector, which increased from $45.1 \%$ to $49.3 \%$ by showing a sharp increase between $2000-2002$, declined to $44.9 \%$ by showing a sharp decrease between $2002-2004$. Although it again increased to $47 \%$ in the period between 2004-2007, it decreased again to $46.6 \%$ between 2007-2009. The employment rate of women in the agricultural sector, which increased linearly between 2009-2010 and increased up to 47.9\%, maintained this value between 2010-2011, but since 2011, the slight increase in 2016-2017 period has decreased continuously with the exception of It fell to $44.4 \%$ in 2018 , taking its lowest value.

\subsection{Data Analysis}

Based on time series data, the biggest problem encountered in econometric analysis is the 'Spurious regression' situation resulting from the non-stationary series. The main source of this problem is that time series carry strong general trends. In this context, unit root test are used to test stationarity (Uzgören et al., 2005). For that reason, before the analysis of the data; logarithmic transformation and difference taking processes were applied to stabilize data. The data's being stationary was checked with Augmented Dickey Fuller (ADF). In the investigation of the effect of the independent variable "employment rate of women in the agricultural sector" on the nominal and real production values of dependent variables "all agricultural products, cereals and other vegetable agricultural products, vegetable products and fruits, beverages and spice crops" LSLeast Squares (NLS and ARMA) method was used.

\section{FINDINGS AND DISCUSSIONS}

\subsection{Data and Econometric Methodology}

Since the data sets of all the variables have a trend, logarithmic transformation and difference taking operation were applied to make the data stationary. It was then checked by Augmented Dickey Fuller (ADF) unit root test, where the data was made stationary. Table 1 shows the final ADF root unit test results. As seen in the table, all of the $p$ values of variables are lower than 0.05 , which mean that the variables don't have a unit root. In other words the variables are stationary.

Table 2: Analysis of the effect of female employment in Agriculture on Agricultural Products Production Values

\begin{tabular}{lll}
\hline Variable & $\begin{array}{l}\text { Level Values } \\
\text { No Fixed Term and Trend }\end{array}$ & \\
\hline & Test & Probability \\
\hline In_n_agricultur2 & -6.586 & .000 \\
\hline In_n_grain2 & -7.405 & .000 \\
\hline In_n_vegetable2 & -4.019 & .000 \\
\hline In_n_fruit2 & -7.211 & .000 \\
\hline In_r_agriculture2 & -6.922 & .000 \\
\hline In_r_grain1 & -4.808 & .000 \\
\hline
\end{tabular}

The effects of women employment in agriculture on agricultural product production values were analyzed by LS-Least Squares (NLS and ARMA) tests. In each equation, the regression analysis was made with 2 variables (One independent variable and one dependent variable) and with 18 observations because of reaching only that maximum number of data on the web site of TUik. Since Büyüköztürk mentions that for some empirical studies a sample size between 10 and 20 may be enough for a succesful research, 18 observations are evaluated as adequate (Büyüköztürk et al, 2018). In addition, the assumptions of the regression analyzes were checked for reliability. For this reason, autocorrelation problem was tested with Durbin Watson statistics, heteroskedasticity problem was tested with White test and multicollinearity problem was tested with VIF indices.

Table 3: Results of Regression Analyzes Assumptions for Autocorrelation, Heteroskedasticity and Multicollinearity

\begin{tabular}{cccccc}
\hline Equation Number & Dependent Variable & Independent Variable & DW & VIF & $\begin{array}{c}\text { White Test } \\
\text { p value }\end{array}$ \\
\hline 1 & In_n_agriculture2t & In_women_emp_rate1t & 2,30 & 1,00 & 0,22 \\
\hline 2 & In_n_grain2t & In_women_emp_rate1t & 2,09 & 1,00 & 0,58 \\
\hline 3 & In_n_vegetable2t & In_women_emp_rate1t & 2,33 & 1,00 & 0,70 \\
\hline 4 & In_n_fruit2t & In_women_emp_rate1t & 2,44 & 1,00 & 0,63 \\
\hline 5 & In_r_agriculture2t & In_women_emp_rate1t & 2,00 & 1,00 & 0,11 \\
\hline 6 & In_r_grain2t & In_women_emp_rate1t & 1,84 & 1,00 & 0,15 \\
\hline
\end{tabular}




\begin{tabular}{cccccc}
\hline 7 & In_r_vegetable2t & In_women_emp_rate1t & 2,07 & 1,00 & 0,64 \\
\hline 8 & In_r_fruit2t & In_women_emp_rate1t & 2,11 & 1,00 & 0,14 \\
\hline
\end{tabular}

As can be seen in Table 3, in all the equations Durbin Watson statistics are in the range of 1.5-2.5 meaning no autocorrelation problem; variance inflation indexes are equal to 1 (Less than 5) pointing to no multicollinearity and all White test $p$ values are lower than 0,05 indicating that heteroskedasticity problem not found (Güriş, et al, 2017). The results of 8 regression equations within the scope of the research are are given in Table 4.

Table 4: Analysis of the Impact of Women's Employment in Agriculture on Agricultural Products Production Values

\begin{tabular}{llllllll}
\hline Dependent variable & Coefficient & $\begin{array}{l}\text { Standard } \\
\text { error }\end{array}$ & $\mathbf{R}^{\mathbf{2}}$ & $\mathbf{A d j . \mathbf { R } ^ { 2 }}$ & $\mathbf{t}$ & $\mathbf{F}$ & $\mathbf{P}$ \\
\hline In_n_agriculture2t & 2.900 & .984 & .367 & .325 & 2.947 & 8.686 & $.009^{* * *}$ \\
\hline In_n_grain2t & 2.361 & 1.591 & .128 & .069 & 1.484 & 2.203 & .158 \\
\hline In_n_vegetable2t & 1.421 & 1.266 & .077 & .016 & 1.123 & 1.260 & .279 \\
\hline In_n_fruit2t & 4.929 & 1.691 & .362 & .319 & 2.915 & 8.499 & $.011^{* *}$ \\
\hline In_r_agriculture2t & 5.032 & 1.701 & .368 & .326 & 2.958 & 8.749 & $.009^{* * *}$ \\
\hline In_r_grain2t & .512 & 1.630 & .006 & .005 & .314 & .098 & .757 \\
\hline In_r_vegetable2t & 3.552 & 1.948 & .182 & .127 & 1.824 & 3.326 & $.088^{*}$ \\
\hline In_r_fruit2t & 7.060 & 2.144 & .419 & .381 & 3.293 & 10.843 & $.005^{* * *}$ \\
\hline
\end{tabular}

LS-Least Squares (NLS and ARMA) Test result; Independent Variable: In_women_emp_rate1, ${ }^{*} p<.01, * * p<.05, * * * p<.1$

The female employment rate in the agricultural sector was used as an independent variable in the equations As the dependent variable, the nominal production value of all agricultural products, the nominal production value of cereals and other vegetable agricultural products, the nominal production value of vegetable products, the nominal production value of fruits, beverage and spice crops, the real production value of all agricultural products, cereals and other vegetable agricultural products real production value, real production value of vegetable products and real production value of fruits, beverages and spice plants were used in equation.

In the agricultural sector, which is an independent variable, the female employment rate is first-order, and the real production value of only cereals and other vegetable crops from dependent variables is stationary when the difference is taken from the first-order and the other 7 dependent variables from the second-order. For this reason, the equation established only by the real production value of cereals and other crop agricultural products has been tested for co-integration and it has not been seen.

When the results are examined, the real production value of fruits, beverages, and spice crops is most at $99 \%$ confidence level of women employment in the agricultural sector $(p=.005<.01)$ then on the real production value of all agricultural products respectively $(p=.009<.01)$ with the nominal production value of all agricultural products $(p=.009<.01)$ above; the nominal production value of fruits, beverages and spice plants at $95 \%$ confidence level $(p=.011<.05)$ It is seen that vegetable products have a positive effect on the real production value if they are above and at $90 \%$ confidence level. Therefore, as the rate of women employment in the agricultural sector increases, it is observed that these production values also increase.

The coefficients of the rate of women employment in the agricultural sector in the equations show that \%1 increase of the women employment in the agricultural sector causes 2.9 billion TL increase of the nominal production values of all agricultural products and 4.9 billion TL increase of the nominal production values of fruits, drinks and spice plants whereas 5 billion dollars increase of the real production values of all agricultural products, 3.5 billion dollars increase of the real production values of vegetable products and 7 billion dollars of real production values of fruits, drinks and spice plants.

It was determined that there was no significant effect of female employment rate on both nominal and real production values of cereals and other crop agricultural products and on the nominal production value of vegetable products.

\section{CONCLUSION}

Rahman (2000) analyses for Bangladesh revealed that the increase in the production of non-grain products such as spices, oilseeds, vegetables has high potential to increase the lucrative employment of women in agriculture and lyengar et al. (2016)'s econometrics study done for the state of Chhattisgarh of India, women played an important role in the agricultural sector to the economy of Chhattisgarh, and women in agriculture, especially rice, pulses and oilseeds production and dealing with the production of these products increases, that increase women's employment in agriculture show. 
Ochieng et al. (2014)'s study for Rwanda, Burundi and the Democratic Republic of Congo, have shown that increased crop productivity is essential to accelerate economic growth and increase the well-being of rural households for women who are normally resource-constrained, and particularly the increase in cassava production positively affects women's employment. In another study of Forsythe et al. (2016) for Nigeria and Malawi, the number of women working in agriculture is positively affected by the increase in the production of Cassava, which is known as a female crop.

For this purpose, when analyzing the results of the equations generated in the agricultural sector of women employment most fruits, beverage and spice crops real output value; then, respectively, with a nominal value of all agricultural products a high degree of production value on real production; fruit and vegetable products beverage and spice crops of moderate value above the real production nominal production value is low if the degree of show that has a positive effect. It was determined that there was no significant effect of female employment rate on both nominal and real production values of cereals and other crop agricultural products and on the nominal production value of vegetable products.

In the practical part of the study, in the period 2000-2018 Turkey's grains and other plant products, vegetable products, fruit, beverage and spice crops agricultural products including agricultural products in these three categories with all TLdenominated and dollar-denominated production values of female employment in agriculture on the real effects were analyzed. The most important result obtained from the research; grains and other agricultural products, except for vegetable production in the other categories of agricultural products in the agricultural sector both in nominal and real values move from the positive effect of female employment in the agricultural sector of female employment in agriculture is a very important factor in the development process of that.

Covering the years 2010-2018 related to the development of each in three different categories in the process of agricultural products (grains and other plant products, vegetable products, fruit, beverage and spice crops) agricultural products both in production values in these three categories including all nominal with very small exceptions, there was a steady increase. However, since there was an increase in the dollar/TL exchange rate in this period, the agricultural production values were divided into the dollar/TL exchange rates for that year and real values were obtained and these values were calculated in dollars, thus achieving more realistic results. Besides the above-mentioned values calculated in dollar terms when the real production is examined for three different categories in both agricultural products in all agricultural products including agricultural products in these three categories of values of real output showed a steady increase until the period between the years 2008-2011, but have been on a steady decline after the period 2008-2011. In this context, the first of the two most important results obtained in the research is that the agricultural sector in Turkey underwent a very serious development process from 2000 to 2008-2011, but since this period, the example has reversed.

The amount of real production of goods produced and made in agriculture due to the scarcity of research on women's employment in Turkey, this study will contribute to the literature.

\section{REFERENCES}

Balaban, U.,(2012), Women's Labour In Development(Toksöz, G.), Book review, Ankara University Journal of SBF, 67 (4),177-182.

Boserup, E. (1970), Women's Role of Economic Development.

Büyüköztürk, Ş., Çakmak, E. K., Akgün, O. E., Karadeniz, S. and Demirel, F. (2018), Scientific Research Methods. Pegem Academic Press, Ankara.

Dogan A., The Contribution Of Agriculture To The Process Of Economic Development In Turkey Example, Erciyes University Journal of the Faculty of Economics and Administrative Sciences, issue 25, 2005, p. 367.

Forsythe, L., Posthumus, H., \& Martin, A. (2016). A crop of one's own? Women's experiences of cassava commercialization in Nigeria and Malawi. Journal of Gender, Agriculture and Food Security, 1(2), 110-128.

Güriş, S., Akay E.Ç. and Güriş A. (2017), Basic Econometrics with Eviews, Der Press, İstanbul.

Iyengar, R. And Gouri, G.P. (2016), Female Employment in Agriculture, International Journal of Recent Trends in Engineering and Research, 206-210.

Kantar, M., (1996), The Roles Of Women Living In The Mountain Villages of Adana and Içel In Social Life And Their Expectations For The Future About These Roles, Unpublished Master's thesis, Çukurova University Graduate School Of Natural and Applied Sciences: Adana.

Karasar, N. (2018). Report Preparation In Research, Nobel Publishing House, Ankara.

Karasar, N. (1999). Scientific Research Method, Nobel Publishing House, Ankara.

Kazgan G., Agriculture And Development,, Istanbul, Der Yayınları, 1983, p.439. 
Makal, A., (2001), Developments In Paid Women's Labour In Turkey In 1950-1965 Period,Ankara University SBF Dergisi,56(2), 117-155.

Ochieng, J., Ouma, E., \& Birachi, E. (2014). Gender participation and decision making in crop management in Great Lakes Region of Central Africa. Gender, Technology and Development, 18(3), 341-362.

Öztürk, M.Y. and Akduran, d.,(2012), Women's Labor Tobacco Producer Women In Agricultural Production (Ed.Ozturk et al.), Heinrich Böll Foundation Publications: Istanbul, Publication No: 4.87-101.

Rahman, P. (2000), Women's Employment in Bangladesh Agriculture: Composition, Determinantsand Scope. Journal of Rural Studies, 16(4), 497-507.

Raney, T., Anriquez, G., Croppenstedt, A., Gerosa, P., Lowder, P.K., Matuschke, I. and Skoet, J. (2011), The Role of Women in Agriculture, Research in Agriculture and Applied Economics, 1-46.

Şahin H., Türkiye Ekonomisi, Uludağ Üniversitesi İktisadi ve İdari Bilimler Fakültesi, Ezgi Kitapevi Yayınları, Bursa, 2002 , s.272.

Şahinöz A., Agriculture Sector, Turkish Economy, Ankara, Image Publications, 2001, p. 78.

Tire, O., (2017), Women's Poverty In Turkey In Terms Of Gender Roles, Blue Atlas, 5 (1), 97-112.

Tolunay, A. and Akyol, A., (2006), Development and Rural Development: Basic Concepts And Definitions, Journal of Süleyman Demirel University Faculty of Forestry,2, 116-127.

Uzgören, N., and Uzgören, E. (2005), Spurious Regression Problem in Time Series Based Econometric Models and an Econometric Model Application Turned Towards Reel Public Expenditure, Academic View, 5, 1-14.

Yavuz, F., (2005), "Agricultural Policy” On Agriculture In Turkey (Ed.Yavuz, F.), Ministry of Agriculture and Rural Affairs: Ankara.Pp. $43-67$.

Yavuz, G., \& Serdaroğlu, U. (2010). Kalkınma ve Kadın (veya Toplumsal Cinsiyet) iliş̧kilendirilişinin Değişimindeki Kavşaklar. içinde: iktisat ve Toplumsal Cinsiyet, U. Serdaroğlu (ed.), Efil Yayınevi, Ankara, 49-101.

Turkish Statistical Institute, www.tuik.gov.tr / accessed 10.02.2020 